\title{
Identification of defensin-encoding genes of Picea glauca: characterization of PgD5, a conserved spruce defensin with strong antifungal activity
}

\author{
Pere Picart ${ }^{1 *}$, Anna Maria Pirttilä², Dora Raventos ${ }^{3}$, Hans-Henrik Kristensen $^{3}$ and Hans-Georg Sahl ${ }^{1}$
}

\begin{abstract}
Background: Plant defensins represent a major innate immune protein superfamily that displays strong inhibitory effects on filamentous fungi. The total number of plant defensins in a conifer species is unknown since there are no sequenced conifer genomes published, however the genomes of several angiosperm species provide an insight on the diversity of plant defensins. Here we report the identification of five new defensin-encoding genes from the Picea glauca genome and the characterization of two of their gene products, named PgD5 and endopiceasin.
\end{abstract}

Results: Screening of a P. glauca EST database with sequences of known plant defensins identified four genes with homology to the known P. glauca defensin PgD1, which were designated PgD2-5. Whereas in the mature PgD2-4 only 7-9 amino acids differed from PgD1, PgD5 had only 64\% sequence identity. PgD5 was amplified from $P$. glauca genomic DNA by PCR. It codes for a precursor of 77-amino acid that is fully conserved within the Picea genus and has similarity to plant defensins. Recombinant PgD5, produced in Escherichia coli, had a molecular mass of $5.721 \mathrm{kDa}$, as determined by mass spectrometry. The PgD5 peptide exhibited strong antifungal activity against several phytopathogens without any effect on the morphology of the treated fungal hyphae, but strongly inhibited hyphal elongation. A SYTOX uptake assay suggested that the inhibitory activity of PgD5 could be associated with altering the permeability of the fungal membranes. Another completely unrelated defensin gene was identified in the EST library and named endopiceasin. Its gene codes for a 6-cysteine peptide that shares high similarity with the fungal defensin plectasin.

Conclusions: Screening of a P. glauca EST database resulted in the identification of five new defensin-encoding genes. PgD5 codes for a plant defensin that displays non-morphogenic antifungal activity against the phytopathogens tested, probably by altering membrane permeability. PgD5 has potential for application in the plant biotechnology sector. Endopiceasin appears to derive from an endo- or epiphytic fungal strain rather than from the plant itself.

Keywords: Spruce defensins, Endophyte, Antifungal activity, Membrane permeabilization

\section{Background}

Plants are exposed to a diverse array of pathogens and pests and their survival depends on different mechanisms for self-defense. Such defenses include physical cell wall barriers [1], as well as the production of a diverse range of molecules which can inhibit the growth of microbial pathogens [2-6]. Among the latter, cationic

\footnotetext{
* Correspondence: perepicart@hotmail.com

'Institut für Mikrobiologie und Biotechnologie, der Universität Bonn,

Meckenheimer, Allee, Bonn 167, 53115, Germany

Full list of author information is available at the end of the article
}

antimicrobial peptides such as defensins, are a most relevant and large family of defense compounds [7-9].

Plant defensins are characterized as small globular, basic, cysteine-rich proteins (45-54 amino acids), containing a triple-stranded antiparallel $\beta$-sheet and one $\alpha$ helix that are stabilized into a compact shape by four disulfide bridges [10-14]. These bridges form a cysteine-stabilized $\alpha$-helix $\beta$-sheet motif $(C S \alpha / \beta)$ that is well conserved in peptides with antimicrobial activity. Two additional structural motifs have been described in the plant defensin structure, namely the $\alpha$-core, encompassing the loop connecting the first $\beta$-strand 
and the $\alpha$-helix, and the $\gamma$-core containing the hairpin loop connecting $\beta$-strands 2 and 3 (L $\beta 2 \beta 3)[15,16]$. Despite the tertiary structure being strongly conserved in plant defensins, the similarity on the primary sequence level is limited to eight cysteine residues, two glycines, one aromatic residue and a glutamic acid in the defined positions [17]. Variations in the amino acid sequences are reflected by small changes in the spatial display of the loops that contribute to the wide range of biological activities observed in these peptides, as a single amino acid substitution can change the spectrum of activity.

Unlike the insect and mammalian defensins, which are mainly active against bacteria $[2,8,18,19]$, plant defensins, with a few exceptions, do not exhibit antibacterial activity [20]. They inhibit the growth of a broad spectrum of fungal plant pathogens, such as Fusarium oxysporum, Verticillium dahliae and Botrytis cinerea, but also of Saccharomyces cerevisiae and human pathogenic fungi such as Candida albicans at very low concentrations in vitro [20]. The precise mode of action of plant defensins is still unclear, and for most plant defensins the molecular components involved in signaling and putative intracellular targets remain unknown [21,22]. Only for the defensin Rs-AFP2 from Raphanus sativus and the defensin Dm-AMP1 from Dahlia merckii, a putative target in the fungal membrane has been identified [23,24]. More recently, it was demonstrated that plant defensins can be internalized into the cytoplasm and interact with specific intracellular targets [25,26]. Moreover, some members of the plant defensins family were found to have additional activities in vitro. These include the inhibition of $\alpha$-amylase [27-29], protein translation [30,31] and proteases [32], as well as zinc tolerance mediators in plant [33], ion channel blockers [34,35], enzymatic activity involved in ascorbic acid redox state [36,37] and activity towards mammalian cells [38-40].

Plant defensins and their antimicrobial effects have been reported from many angiosperm plants, including monocots and dicots. The genome of Arabidopsis thaliana contains 14 different defensin genes that respond to various stresses [8]. However, polypeptides with similar properties have not been well studied in gymnosperms. The availability of a substantial expressed sequence tag (over 300000 ESTs) resource developed for Picea glauca $[41,42]$ has resulted in the identification of only one expressed defensin gene, $P g D 1$ [43], and one antifungal protein [44]. This prompted us to perform a wide bioinformatics analysis to screen for novel spruce defensins.

Here, we describe the identification of new Picea defensin genes, and the characterization of one of the defensin peptides, PgD5. The identification of new defensins from $P$. glauca expands our knowledge on conifer genomics and raises interest to study the potential of spruce defensins as fungicidal agents.

\section{Results}

\section{Defensin-like peptides in Picea glauca genome}

The $P$. glauca EST database was first screened with the amino acid sequence of Picea glauca defensin 1 (PgD1, GenBank:AAR84643) by the TBLASTN program. TBLASTN is especially suitable for the discovery of distant homologues with a conserved sequence motif [45]. This initial screening yielded four different EST hits, GQ03918_C16, GQ02811_I12, GQ03707_G02 and GQ01307_A13, which shared similarity to PgD1. The complete coding sequences of the isolated ESTs were then named P. glauca defensin 2 to 5 (PgD2-5), respectively. When the deduced coding sequences of the new PgDs were compared to PgD1, high similarity was observed for PgD2-4 with $83-86 \%$ sequence identity (Figure 1A). In contrast, only $60 \%$ identity was observed when PgD1 was compared with PgD5.

Alignment analysis of the deduced amino acid sequences of $P g D 2-5$ revealed that $P g D 2$ codes for a precursor of 83 amino acid with the highest similarity to defensin 3 from Pinus sylvestris [GenBank:JN980401] at the 93\% similarity level (data not shown). PgD3 and PgD4 code for 83 amino acid peptides sharing 100\% and 99\% identities with an unknown protein from Picea sitchensis [GenBank:ABK21016], respectively (data not shown). The deduced amino acid sequences of $\mathrm{PgD} 3$ and $\mathrm{PgD} 4$ were identical, except for a substitution of Ser for Gly in position 73 (numbering according to PgD1 from P. glauca) (Figure 1A). PgD5 codes for a precursor of 77-amino acids. Alignment of the deduced amino acid sequence revealed that the mature region of PgD5 shares high similarity with members of the gymnosperms, displaying 64\% homology to both the Scots pine defensin 2 [Swiss-Prot:A4L7R8.1] [46] and the defensin 1 from Picea glauca [GenBank: CAA62761.1] [43], respectively, as well as to unrelated plant defensins from different families (Figure 1B). For instance, it displays $62 \%$ similarity to defensin vv-AMP1 from Vitis vinifera [47] and $62 \%$ similarity to putative defensin 1 from Olea europaea [48]. PgD5 shares 12 conserved amino acids, including eight cysteine and two glycine residues, as well as one glutamic acid and one aromatic residue at conserved positions. These amino acids are common to all plant defensins [17]. Disulphidebridge analysis done with DIpro confirmed that the eight cysteine residues of PgD5 are connected by four disulfide bridges (Figure 1B).

When the $P$. glauca EST database was further screened with the amino acid sequences of several other gymnosperm defensins, no additional new defensins were identified. Surprisingly, screening of the P. glauca EST database with the amino acid sequence of plectasin [Swiss-Prot: Q53I06.1] [49] yielded one EST hit, GQ0132.B7_K03, which shared $58 \%$ similarity to plectasin (Additional file 1). The complete coding sequence of EST GQ0132.B7_K03 


\begin{tabular}{|c|c|c|}
\hline \multicolumn{3}{|l|}{ A } \\
\hline PgD1 & \multicolumn{2}{|c|}{ MADKGVCSRLSALFLLVLLVISIGMMQLELAEARTCKTPSGKFKGVCASSNNCKNVCQTE } \\
\hline PgD2 & \multicolumn{2}{|c|}{ MAGKGVGNRLSALFLLVLLVIS IGMMQVEMAEARTCKTPSGKFKGYCVSSTNCKSVCRTE } \\
\hline PgD3 & \multicolumn{2}{|c|}{ MAAKGVGGRLSALFLLVLLVIS IGMMQVEVAEARMCKTPSSKFKGYCVSSTNCKNVCRTE } \\
\hline PgD4 & \multicolumn{2}{|c|}{ MAAKGVGGRLSALFLLVLLVIS IGMMQVEVAEARMCKTPSSKFKGYCVS STNCKNVCRTE } \\
\hline PgD5 & \\
\hline PgD1 & \multicolumn{2}{|c|}{ 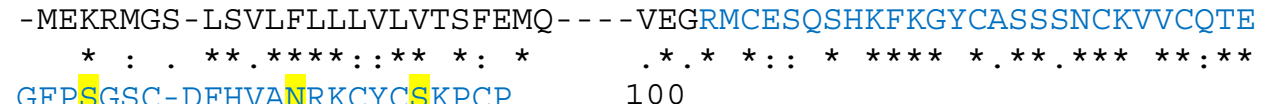 } \\
\hline PgD2 & \multicolumn{2}{|l|}{ GFPSGSC-DFHVAGRKCYCYKPCP $\quad 86$} \\
\hline PgD3 & \multicolumn{2}{|l|}{ GFPTGSC-DFHVASRKCYCYKPCP 83} \\
\hline PgD4 & \multicolumn{2}{|l|}{ GFPTGSC-DFHVAGRKCYCYKPCP 83} \\
\hline PgD5 & \multicolumn{2}{|l|}{$\begin{array}{cc}\text { KFLTGSCRDTHFGNRRCFCEKPC } & 60 \\
*: * * * * * \ldots *:^{*}: * * * * & \circ \text { Similarity } \\
& \text { to PgD1 }\end{array}$} \\
\hline B & \multicolumn{2}{|c|}{$\begin{array}{l}\text { Similarity } \\
\text { to PgD5 }\end{array}$} \\
\hline \multicolumn{3}{|c|}{ RMCESQSHKFKGYCASSSNCKVVCQTEKFLTGSCRDTHFGNRRCFCEKPC 100} \\
\hline gb|ABK21016.1| & RMCKTPSSKFKGYCVSSTNCKNVCRTEGFPTGSC-DFHVASRKCYCYKPC & 64 \\
\hline $\operatorname{sp}|A 4 L 7 R 8.1|$ & RMCKTPSAKFKGYCVSSTNCKNVCRTEGFPTGSC-DFHITSRKCYCYKPC & 64 \\
\hline gb|AAR84643.1| & RTCKTPSGKFKGVCASSNNCKNVCQTEGFPSGSC-DFHVANRKCYCSKPC & 64 \\
\hline gb $\mid$ CAA62761.1| & RTCKTPSGKFKGVCASRNNCKNVCQTEGFPSGSC-DFHVANRKCYCSKPC & 62 \\
\hline ref|XP_002274354.1| & RTCESQSHRFKGTCVRQSNCAAVCQTEGFHGGNCR--GFR-RRCFCTKHC & 62 \\
\hline gb $|A B S \overline{7} 2000.1|$ & RTCESQSHRFKGSCVSKSNCAAVCQTEGFPDGYCR--GFR-RRCFCSKHC & 62 \\
\hline ref|XP $003628977.1 \mid$ & RTCESQSHKFKGPCASDHNCASVCQTERFSGGHCR--GFR-RRCFCTTHC & 62 \\
\hline gb|AAŪ $4859.1 \mid$ & RTCKTQSSKFKGYCLSDTNCRNVCRTEGFPTGSC-DFHVASRKCYCYKPC & 60 \\
\hline gb|AEW08922.1| & RTCKTPSGKFKGYCVNSTNCKNVCRTEGFPTGSC-DFHVAGRKCYCYKPC & 60 \\
\hline gb $\mid$ ACV84381.1 & RDCVSQSHNFKGACLSSSNCPAVCRTENFPDGECHTPHFE-RKCFCKRPC & 60 \\
\hline sp $|A 3 F P F 2.1|$ & RTCESQSHRFKGACLSDTNCASVCQTEGFPAGDCK--GAR-RRCFCVKPC & 60 \\
\hline gb|AAL15885.1| & RTCESQNSHRFKGPCVRKSNCASVCQTEGFHGGQCR--GFR-RRCFCTKHC & 60 \\
\hline gb|EAY86781.1 & RHCLSQ̃SHRFKGMCVSSNNCANVCRTESFPDGECKSHGLE-RKCFCKKPC & 58 \\
\hline gb $|A C B 20518.1|$ & RYCLSQSHRFKGLCMSSSNCANVCQTENFPGGECKADGAT-RKCFCKKIC & 58 \\
\hline gb|ACV84379.1 & RNCLSQSHNFKGACLSSSNCAAVCRTENFPDGECHAPHYE-RKCFCKRPC & 58 \\
\hline ref|NP_001234987.1| & RTCESQSHRFKGPCLSDTNCGSVCRTERFTGGHCR--GFR-RRCFCTKHC & 58 \\
\hline gb|ADR $30067.1 \mid$ & RTCESQSHRFKGPCVSDTNCASVCRTERFSGGHCR--GFR-RRCFCTKHC & 58 \\
\hline gb|BAA95697.1| & RTCESQSSHRFKGPCSRDSNCATVCLTEGFSGGDCR--GFR-RRCFCTRPC & 58 \\
\hline $\mathrm{gb}|\mathrm{ABO} 36637.1|$ & RTCESQSHRFKGPCVSEKNCASVCETEGFSGGDCR--GFR-RRCFCTRPC & 58 \\
\hline gb|AAL35366.1 & RTCESQSHRFKGVCASETNCASVCQTEGFSGGDCR--GFR-RRCFCTRPC & 58 \\
\hline gb|ACG30752.1 | & 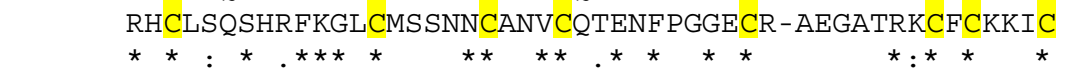 & 58 \\
\hline Consensus & $--C------a-G-C-----C---C-E-----G-C--------C-C---C$ & \\
\hline \multicolumn{3}{|c|}{$\begin{array}{l}\text { Figure } 1 \text { Alignment analysis of the deduced amino acid sequences of Picea glauca defensin-encoding genes discovered by database } \\
\text { searches. (A) PgDs retrieved by screening the P. glauca EST database using the amino acid sequence of P. glauca defensin } 1 \text { (PgD1). The percentage } \\
\text { similarity compared to PgD1 is indicated in the last column. The major differences between PgD1 and closely related PgD2, PgD3 and PgD4 are } \\
\text { indicated by yellow. The deduced region of mature PgDs is indicated by blue amino acids. (B) Alignment analysis of the deduced mature region of PgD5 } \\
\text { peptide with other members of the defensin family. The percentage similarity compared to PgD5 is indicated in the last column. [GenBank:ABK21016.1] } \\
\text { unknown Picea sitchensis; [Swiss-Prot:A4L7R8.1] defensin 2 Pinus sylvestris; [GenBank:AAR84643.1] defensin PgD1 Picea glauca; [GenBank:CAA62761.1] } \\
\text { putative gamma-thionin protein Picea abies; [GenBank:XP_002274353.1] VV-Amp defensin Vitis vinifera; [GenBank:ABS72000.1] putative defensin } 1 \text { Olea } \\
\text { europaea; [GenBank:XP_003628977.1] defensin Medicago truncatula; [GenBank:AAU04859.1] defensin precursor Ginkgo biloba; [GenBank:AEW08922.1] } \\
\text { hypothetical protein Pinus radiata; [GenBank:ACV84381.1] defensin precursor Triticum durum; [Swiss-Prot:A3FPF2.1] defensin-like protein Nelumbo nucifera; } \\
\text { [GenBank:AAL15885.1] putative gamma-thionin Castanea sativa; [GenBank:EAY86781.1] hypothetical protein Oryza sativa; [GenBank:ACB20518.1] defensin } \\
\text { precursor Saccharum officinarum; [GenBank:ACV84379.1] defensin precursor Triticum aestivum; [GenBank:NP_001234987.1] protease inhibitor precursor } \\
\text { Glycine max; [GenBank:ADR30067.1] defensin D2 Phaseolus vulgaris; [GenBank:BAA95697.1] thionin like protein Nicotiana tabacum; [GenBank:ABO36637.1] } \\
\text { defensin protein Solanum lycopersicum; [GenBank:AAL35366.1] defensin protein precursor Capiscum annuum; [GenBank:ACG30752.1] defensin Zea mays. } \\
\text { The consensus sequence containing the eight cysteine residues, two glycines, an aromatic residue and a glutamic acid, common to all plant defensins, is } \\
\text { indicated below. The disulfide bridge organization within the PgD5 sequence is indicated below the consensus sequence. }\end{array}$} \\
\hline
\end{tabular}




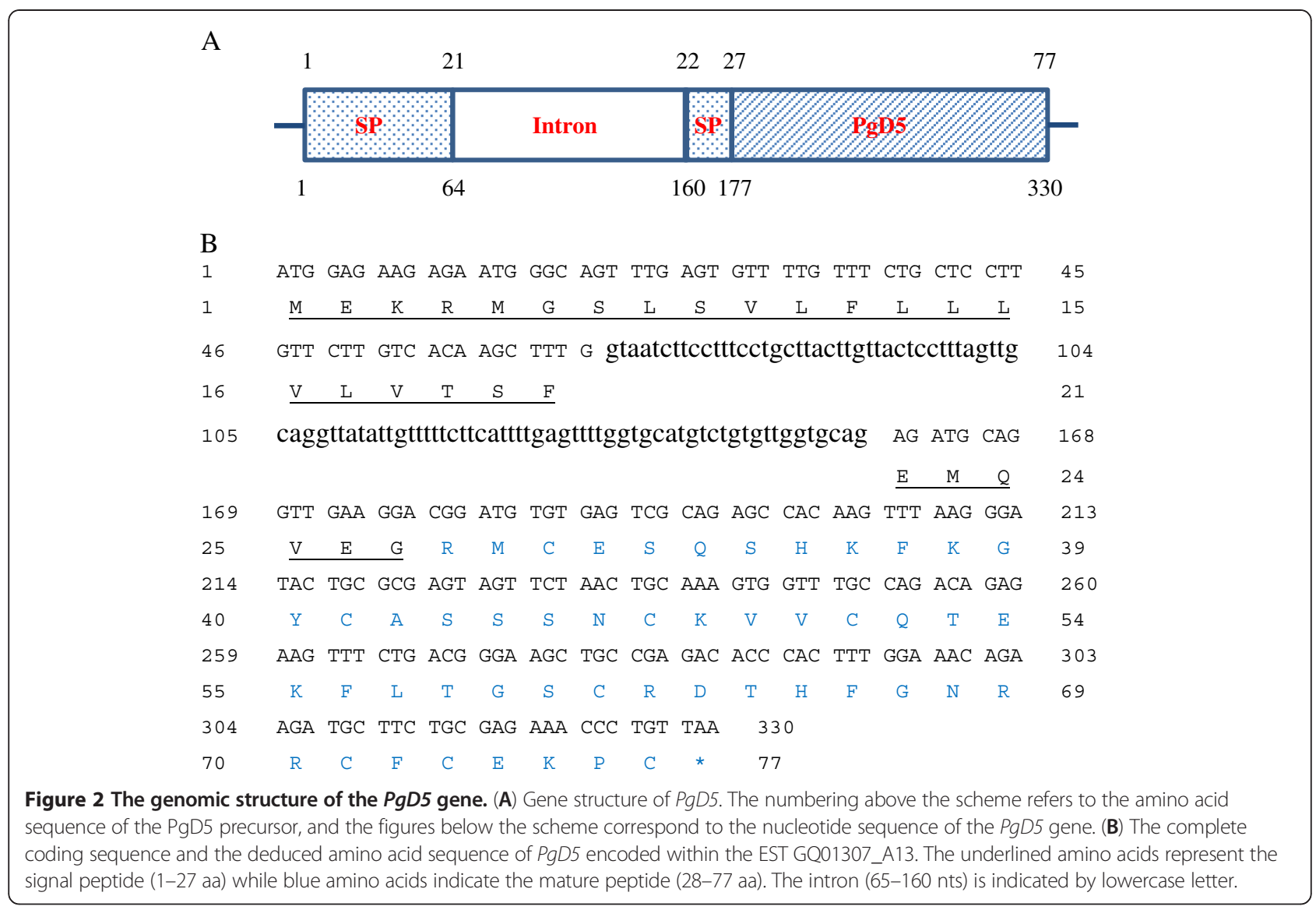

was $273 \mathrm{bp}$ in size and codes for a predicted 90 -amino acid peptide. SignalP results showed that the first 20 amino acids code for a signal peptide followed by a 30 -amino acid propeptide and a mature peptide of 40 amino acids (Additional file 2). Comparative analysis of the deduced amino acid sequence of mature peptide with other members of the defensin family revealed that the peptide shares a disulphide bridge pattern common to defensins of fungi, insects and other invertebrates [50,51]. It contains three disulphide bridges in contrast to all plant defensins that typically have four disulphide bridges (Additional file 3).

The most distantly related $P g D 5$ and the gene encoded within EST GQ0132.B7_K03 were selected for further analysis. In both cases, the cDNA library containing the corresponding genes was exclusively isolated from actively elongating roots tips free of mycorrhiza.

\section{Genomic and in silico characterization of $\mathrm{PgD} 5$ and endopiceasin}

Primers were designed based on the EST GQ01307_A13 sequence and PCR was carried out to amplify the complete coding sequence of $P g D 5$ using genomic DNA of $P$. glauca. Genomic amplification of the sample resulted in a product of about $330 \mathrm{bp}$ and a comparative analysis with the EST GQ01307_A13 revealed that a 96 bp-intron interrupts the predicted signal peptide (Figure 2A). SignalP analysis showed that the first 27 amino acids code for a signal peptide followed by a 50 -amino acid mature peptide (Figure 2B). PA-SUB predicted that the signal peptide of PgD5 directs its product to the extracellular space of plant cells. The peptide parameters obtained from the Expasy-Compute $\mathrm{pI} / \mathrm{Mw}$ tool showed that PgD5 has a predicted mono-isotopic mass of $5721.56 \mathrm{Da}$ and is highly basic with a net charge of +5 and an isoelectric point above 8.9. Seven different spruce species, namely $P$. glauca and $P$. mariana (native to North America), P. smithiana, $P$. wilsonii and $P$. orientalis (native to Asia), and P. abies and $P$. omorika (native to Europe) were selected to isolate the corresponding putative defensins from genomic DNA. PCR reactions resulted in amplification of seven genomic copies of $P g D 5$, which were sequenced. Alignment analysis of these genomic sequences revealed a very high level of similarity (99\%) between the sequences at nucleotide level where the majority of mismatches occurred in the intron region (Additional file 4). The sequences at the deduced amino acid level were $100 \%$ identical, indicating that the peptide is fully conserved within the genus Picea.

In the case of endopiceasin, primers were designed based on the EST GQ0132.B7_K03 sequence and PCR 


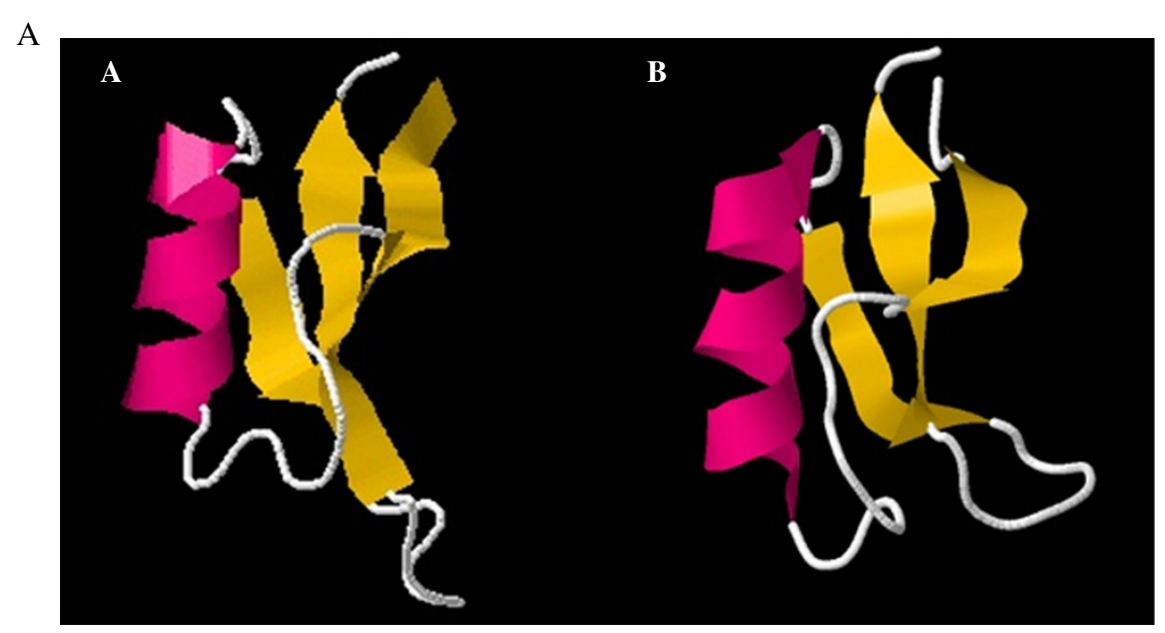

$\mathrm{B}$

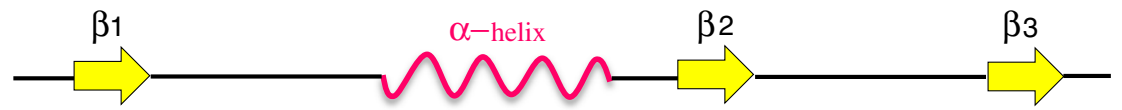

RMCESQSHKFKGYCASSSNCKVVCQTEKFLTGSCRDTHFGNRRCFCEKPC

Figure 3 Protein structure of PgD5. (A) Comparison of the tertiary structure of PgD5 from Picea glauca (A) and defensin A from Nicotiana tabacum (B) by homology-based models. The a-helix and $\beta$-sheet structures are represented in pink and yellow, respectively. Models were developed using the I-TASSER website for protein structure and function predictions. (B) Secondary structure of PgD5. Secondary structure elements ( $\alpha$-helix and $\beta$-strands) of PgD5 are given below. Amino acid residues forming the a-core are underlined while the amino acid residues forming the $\gamma$-core are double underlined.

was carried out to amplify the complete coding sequence of the mature peptide using genomic DNA of $P$. glauca. Genomic amplification was unsuccessful as no product was obtained. These results suggest that the defensin is not encoded by the plant genome itself and we suggest to designate this defensin as endopiceasin.
Comparative modeling of the deduced amino acid sequence suggested that the tertiary structure of PgD5 closely resembles that of $\mathrm{NaD1}$, a floral defensin from Nicotiana tabacum (UniProtKB:P32026). These defensins contain an invariant tetradisulfide array and have the common cysteine-stabilized $\alpha / \beta$ structure $(C S \alpha / \beta)$

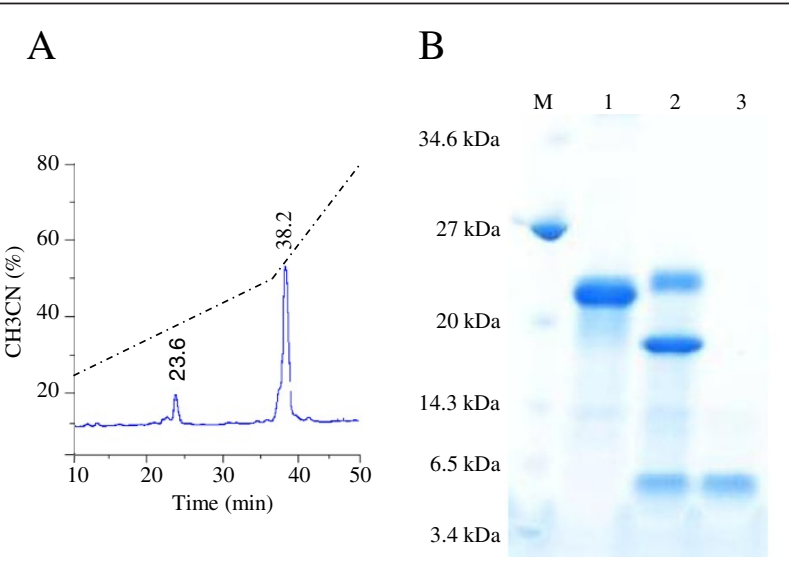

C

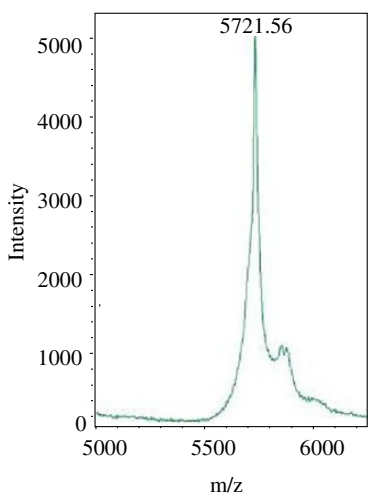

Figure 4 Purification of recombinant PgD5 produced by E. coli BL21 (Origami pLys S) DE3. (A) RP-HPLC chromatography of the His6SUMO-PgD5 fusion protein after cleavage with the SUMO protease. Elution times are marked. (B) SDS-PAGE analysis of the His6-SUMO-PgD5 fusion before and after SUMO protease treatment. Lane M, low molecular weight marker (New England Biolabs). Lane 1, Purified fusion protein by Ni-NTA column. Lane 2, SUMO protease cleavage products after 60 min. Lane 3, Purified PgD5 peptide after SUMO protease digestion and reverse-phase chromatography. (C) Mass spectrometric analysis of recombinant PgD5 after separation from the His6-SUMO tag using reversephase chromatography. 
composed of three antiparallel $\beta$-strands and one $\alpha$ helix which are organized in a $\beta \alpha \beta \beta$ configuration (Figure 3A). Analysis of the PgD5 primary sequence identified $\gamma$-core and $\alpha$-core motifs [52], as shown in Figure 3B.

\section{Recombinant production and purification of PgD5}

The His6-SUMO-PgD5 fusion was successfully expressed in E. coli BL21 (Origami pLys S) DE3. The recombinant fusion protein of $18 \mathrm{kDa}$ was efficiently produced in soluble form and purified to $>90 \%$ purity by Ni-NTA column chromatography in a single step (Figure 4A). The SUMO-tag was removed by the Sumo protease. The resulting protein products were further purified using a C18 reversed phase chromatography column and a TFA/ acetonitrile gradient. Recombinant PgD5 eluted at 23.6 min (at 38\% solvent B) while the digested SUMO-tag eluted at $38.2 \mathrm{~min}$ (at $52 \%$ solvent B) (Figure 4B). SDSPAGE analysis confirmed that PgD5 was successfully separated from the cleaved tag and purified to homogeneity (Figure 4A). The purified peptide was further characterized by MALDI-TOF-MS. MALDI-TOF-MS analysis yielded a mass of $5721.56 \mathrm{Da}$ for the purified peptide, which is $8 \mathrm{Da}$ less than the theoretical mass calculated with the Expasy-Compute $\mathrm{pI} / \mathrm{Mw}$ tool of $5729.66 \mathrm{Da}$ (Figure 4C). These data indicate that the four disulphide bridges which are common to all plant defensins were correctly formed. Incubation of the peptide in $2 \mathrm{mM}$ DTT reduced the disulphide bridges and completely inactivated the peptide.

\section{Antimicrobial activity of purified PgD5}

Antifungal activity of PgD5 was assayed by microspectrophotometry using a dose-response growth inhibition assay. PgD5 significantly inhibited the fungal growth over time in all fungal isolates tested even at very low concentrations. PgD5 was most active against V. dahliae (Figure $5 \mathrm{~A}$ ) and $\mathrm{B}$. cinerea (Figure $5 \mathrm{~B}$ ), with $\mathrm{IC}_{50}$ values of $2 \mu \mathrm{g} / \mathrm{mL}$ and $4 \mu \mathrm{g} / \mathrm{mL}$, respectively. However, PgD5 was less effective against $F$. oxysporum with an $\mathrm{IC}_{50}$ value of $11 \mu \mathrm{g} / \mathrm{mL}$ (Figure $5 \mathrm{C}$ ). Treatment of $V$. dahliae spores, the causal agent of wilting disease, with a peptide concentration of $3 \mu \mathrm{g} / \mathrm{mL}$ resulted in $>90 \%$ growth inhibition, and a concentration of $8 \mu \mathrm{g} / \mathrm{mL}$ completely arrested spore germination (data not shown). The antifungal activity of PgD5 was also determined in vitro with
A

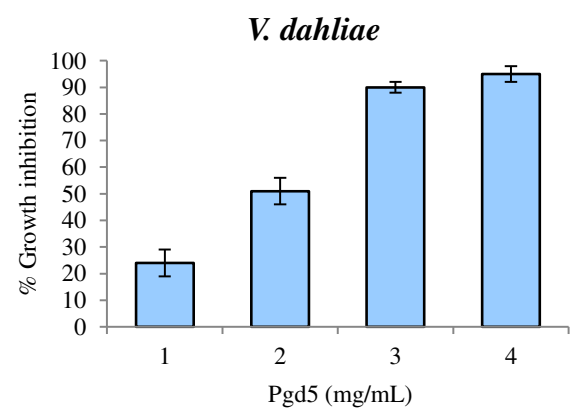

$\mathrm{C}$

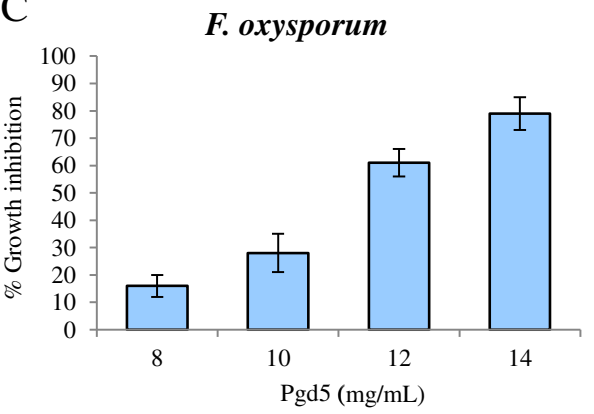

B

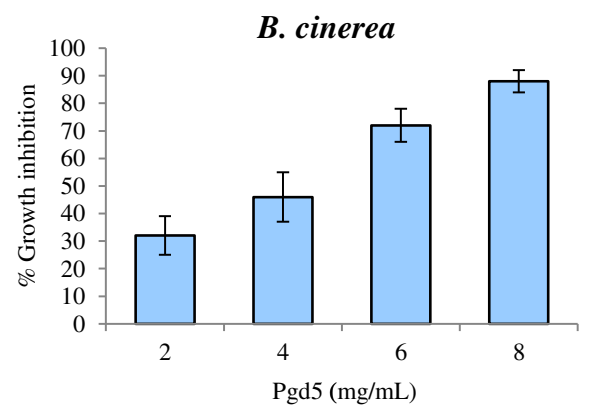

$\mathrm{D}$

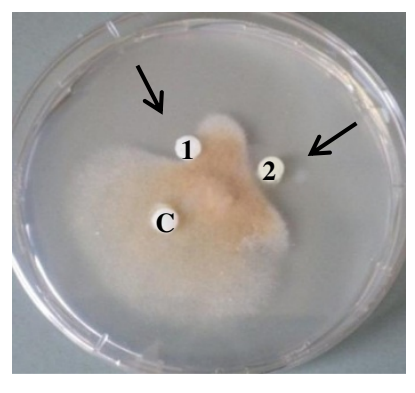

R. solani

Figure 5 Recombinant PgD5 possesses antifungal activity. (A-C) Dose-response growth inhibition assay. Growth inhibition of V. dahliae (A), B. cinerea (B) and F. oxysporum (C) in the presence of indicated concentrations of recombinant PgD5 was determined by microspectrophotometric readings taken every 24 hours at $A_{595}$ and compared to the untreated fungal controls. The data is represented as the percentage of fungal growth as compared to the untreated control reactions without peptide. The experiment was repeated three times and the standard deviation for each reaction was less than 5\%. Growth inhibition was determined after 48 hours of growth for $F$. oxysporum and B. cinerea and after 72 hours for $V$. dahliae. (D). Effect of purified recombinant PgD5 on mycelial growth of $R$. solani: disk C, sterile distilled water; disks 1 and 2 correspond to 3 and $6 \mu \mathrm{g}$ of recombinant PgD5, respectively. The arrows indicate zones of growth inhibition. 
a plate assay on Rhizoctonia solani. As illustrated in Figure 5D, there are inhibition zones of $R$. solani in areas containing sterile discs of filter paper on which various concentrations of purified PgD5 were applied. Distilled water served as the negative control.

One characteristic feature of many cationic antimicrobial peptides is their ability to permeabilize the plasma membrane of target organisms. We examined membrane permeabilization using the fluorometric SYTOX Green dye, which is taken up only by cells with compromised plasma membrane. Microscopical analyses of fungal hyphae treated with PgD5 did not reveal increased hyphal branching and morphologically altered hyphae that are typically induced by some plant defensins [7,50,52] (Figure 6). However, PgD5 strongly inhibited elongation of fungal hyphae. By measuring the SYTOX green uptake by fluorescence microscopy we observed that PgD5 induced membrane permeabilization in the three fungi tested. Hyphae of Pgd5-treated B. cinerea, F. oxysporum and $V$. dahliae had strong fluorescence in the cytosol
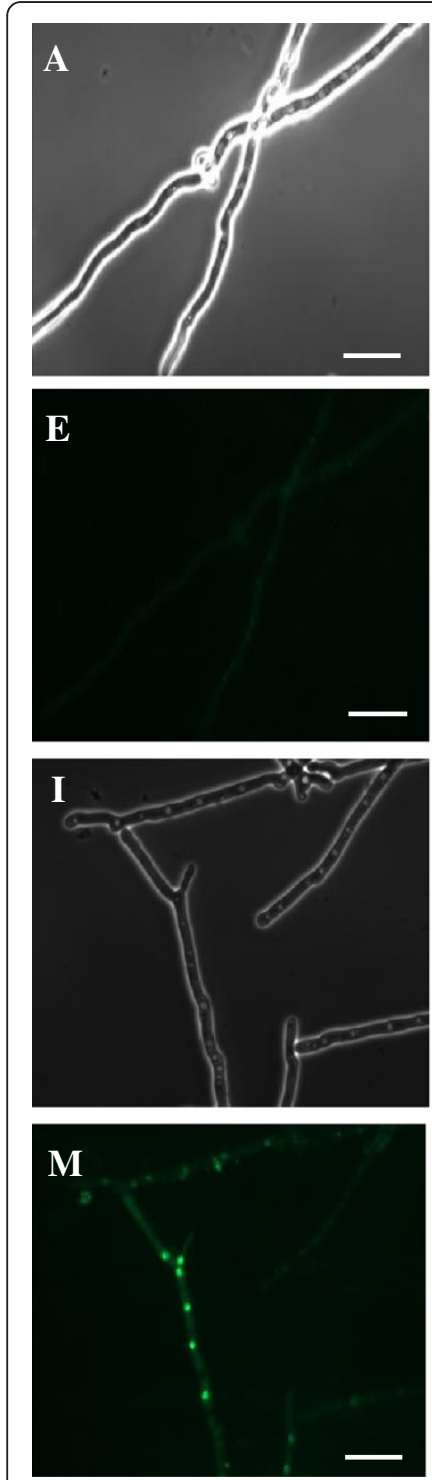
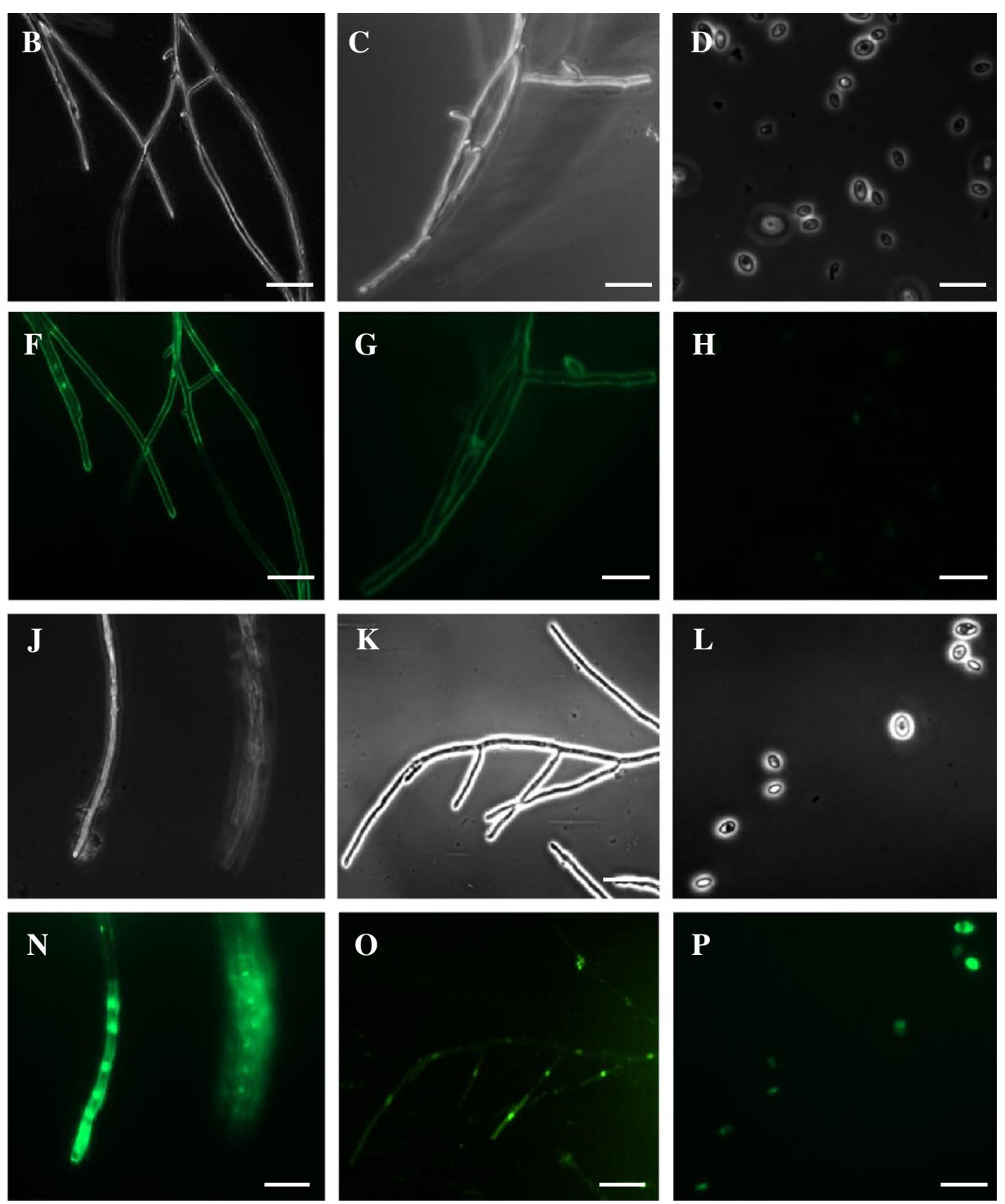

Figure 6 Fluorescence microscopy analysis of SYTOX Green uptake during the membrane permeabilization assay. (A-D). Phase contrast images and (E-H) fluorescent images of untreated F. oxysporum, B. cinerea, V. dahliae and S. cerevisiae cells, respectively. (I-L) Phase contrast images and (M-P) fluorescent images of PgD5 treated F. oxysporum, B. cinerea, V. dahliae and S. cerevisiae cells respectively. Fungi were grown for $48 \mathrm{~h}$ in the presence of PgD5 at peptide concentrations of $11 \mu \mathrm{g} / \mathrm{mL}$ for F. oxysporum, $4 \mu \mathrm{g} / \mathrm{mL}$ for B. cinerea, and $2 \mu \mathrm{g} / \mathrm{mL}$ for V. dahliae. S. cerevisiae cells were grown for $1 \mathrm{~h}$ in the presence of PgD5 at $11 \mu \mathrm{g} / \mathrm{mL}$. Afterwards, fungal hyphae and yeast cells were washed with $0.1 \mathrm{M}$ Tris- $\mathrm{HCl}$, pH 8.0, stained with $0.2 \mathrm{mM}$ SYTOX for $30 \mathrm{~min}$ at $25^{\circ} \mathrm{C}$ with periodic agitation and subjected to fluorescent microscopic analysis. Bar $=20 \mu \mathrm{m}$. 
(Figure 6M-O), especially in the nuclei, when compared to the untreated fungi that showed no fluorescence (Figure 6E-G). The ability of PgD5 to permeabilize the plasma membrane was also tested in S. cerevisiae. By fluorescence microscopy, Pgd5-treated S. cerevisiae cells showed strong SYTOX Green fluorescence in the cytosol (Figure 6P) as compared to negative controls (cells grown without peptide) (Figure $6 \mathrm{H}$ ), indicating that PgD5 also induced membrane permeabilization in the yeast cells. In contrast to these findings, PgD5 was not active against Candida albicans at the concentration of $50 \mu \mathrm{g} / \mathrm{mL}$ (data not shown).

\section{Recombinant PgD5 is heat-stable and moderately sensitive to cations}

PgD5 was tested for its stability at various temperatures using the antifungal growth assay against $V$. dahliae. PgD5 was remarkably stable at temperatures of up to $100^{\circ} \mathrm{C}$. Seventy one percent of its antifungal activity was retained after $30 \mathrm{~min}$ of treatment at $75^{\circ} \mathrm{C}$ and $61 \%$ at $100^{\circ} \mathrm{C}$ (Figure 7A). Analysis of the effect of monovalent and divalent cations on antifungal activity of PgD5 showed that the divalent cation $\mathrm{Ca}^{2+}$ diminished about $50 \%$ the antifungal activity of the peptide at the concentration of $5 \mathrm{mM}$. The monovalent cation $\mathrm{K}^{+}$had no effect on the antifungal activity of PgD5 at the concentration of $50 \mathrm{mM}$ (Figure 7B).

\section{Discussion}

\section{Characterization of plant defensin-encoding genes of Picea glauca}

Plant defensins are a prominent family of cationic peptides that are ubiquitous among the plant kingdom and represent an important part of the plant innate immune system. Previously, only two antifungal proteins have been described in P. glauca. The first PgD1 (Picea glauca Defensin 1), is a plant defensin of 50 amino acids that displays antifungal activity against Cylindrocladium floridanum, Fusarium oxysporum, and Nectria galligena at $14 \mu \mathrm{g} / \mathrm{mL}$ [43]. The second is an embryo-abundant protein of 109 amino acids that shares $85 \%$ similarity with an antifungal protein of Ginkgo biloba [44] but lacks the characteristic features of plant defensins.

In the present work, the screening of the $P$. glauca EST database using the TBLASTN algorithm resulted in identification of five new defensin-encoding genes (Figure 1 and Additional file 1). In addition to expanding the list of existing spruce defensins, our research on $P$. glauca defensins and their encoding genes gives insight into conifer biology and genomics. Our results show that the habitual family of defensins found in angiosperms [53] is also present in gymnosperms, giving another example of the high diversity of plant defensins.

Defensins are expressed in different plant tissues including leaves, pods, tubers, fruits, roots, bark and floral organs $[2,8,19]$. They provide specific defensive capacity to the plant. The cDNA library containing the EST GQ01307_A13 and EST GQ0132.B7_K03 was constructed from mRNA exclusively isolated from actively elongating roots tips free of mycorrhiza, indicating that PgD5 and endopiceasin genes might be expressed in a tissue-specific manner, only in the roots. To the best of our knowledge, these peptides are, along with defensin SPI1 from Norway spruce (Picea abies) [54], the only reported plant defensins that are expressed exclusively in the plant root system.

Endopiceasin resembles the structure of classical defensins of fungi, insects and invertebrates with 6 cysteine residues connected by three disulphide-bridges that stabilize the CS $\alpha \beta$ motif $[2,8,55-57]$. PCR for isolation of endopiceasin did not result in a product and efforts to amplify the gene by changing the PCR conditions were unsuccessful. DNA isolated from higher plants may originate from symbiotic microbes called endophytes occupying plant

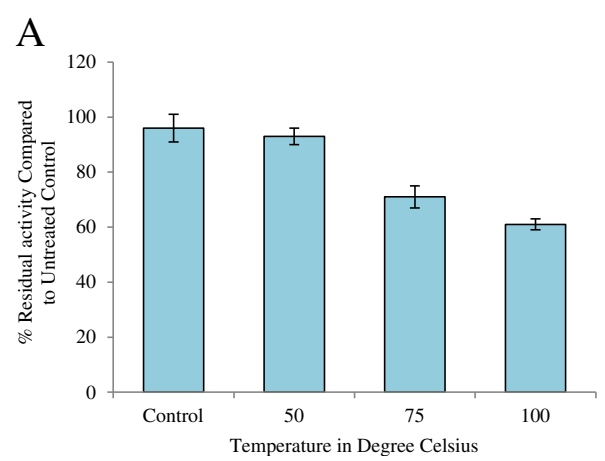

B

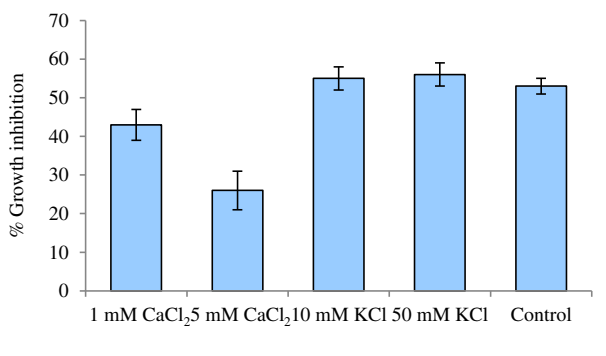

Figure 7 Thermal stability and effect of cations on PgD5 activity. (A) Temperature stability of PgD5. After heat treatment, the remaining antifungal activity of PgD5 was scored against the control without heat treatment $\left(25^{\circ} \mathrm{C}\right)$. (B) Effect of the presence of monovalent and divalent cations on PgD5 activity. The antifungal activity of PgD5 (at the dose of $2 \mu \mathrm{g} / \mathrm{mL}$ ) was scored against $V$. dahliae by incubating the peptide in the presence of various concentrations of monovalent and divalent cations. The control was treated in the absence of cations in the medium. 
tissues at surprisingly high frequencies. Accordingly, few reports have described DNA sequences attributed to gymnosperms and angiosperms, which actually belong to specific endophytes [58,59]. We believe that EST GQ0132. B7_K03 present in P. glauca cDNA library originates from an endophyte or epiphytic fungal strain colonizing the root system of $P$. glauca. Experiments are in progress to further identify the origin of the endopiceasin peptide. In this context, the high degree of similarity between endopiceasin and plectasin might be of special interest because plectasin is a potent peptide antibiotic with strong therapeutic potential $[49,51]$. We also confirmed the similarity of endopiceasin to plectasin by analysing its mode of action. Endopiceasin was only active against gram-positive bacteria and its activity was based on inhibition of cell wall biosynthesis and lipid II binding (manuscript in preparation). In fact, endophytes that colonize internal plant tissues as mutualists have a role in protection of the plant against pathogens [60], and our report indicates that antibacterial defensins from endophytes might play a significant role in such protection.

\section{Characteristic features of PgD5}

PgD5 showed high similarity at amino acid level with related and unrelated plant defensins of the Gymnospermae family (Figure 1B), which supports the idea of a common origin of plant defensins. The presence of a typical secretion signal peptide is one of the characteristic features of plant defensins [61]. Based on the precursor protein structure, PgD5 groups with Class I of the defensin family [2], containing an N-terminal signal peptide followed by the mature defensin domain. This is in contrast to Class II defensin peptides which have an additional C-terminal prodomain.

PgD5 appears completely conserved within the genus Picea. There are many reports of plant defensins showing more than $96 \%$ identity within the same genus and differing only by one or two amino acids [62-64], which turns into different antimicrobial activities. However, to our best knowledge, this is the first report on a plant defensin being fully conserved within a genus or, at least, within the seven different Picea sp. analyzed in this work. This suggests a very specific role for the $P g D 5$ gene being highly conserved during evolution of the genus Picea.

\section{Antifungal activity of PgD5}

PgD5 exhibited strong antifungal activity inhibiting growth of hyphae of four agronomically important pathogens: B. cinerea, an airbone pathogen of broadleaved and coniferous trees; $R$. solani, a soilborne pathogen of economically important agricultural plants and $F$. oxysporum and $V$. dahliae, which are the leading causes of wilting disease (Figure 5). Based on the structural and functional similarity, PgD5 was included into the "non- morphogenic" group of plant defensins, which slow down hyphal elongation but do not induce marked morphological distortions $[8,18,47]$. The activity exerted by PgD5 against the phytopathogenic fungi and S. cerevisiae was linked to alteration of fungal membrane permeability. The nuclei of these permeabilized hyphae appeared intact and the cytoplasm unaltered with no signs of granulation of the hyphal cytoplasm, which is observed in some defensins. However, PgD5 was not active against C. albicans at concentration of $50 \mu \mathrm{g} / \mathrm{mL}$. Probably PgD5 interacts with essential plasma membrane structures of S. cerevisiae that are not present in C. albicans, causing a structural disruption and alteration of the membrane permeability. However, more studies are necessary to discern whether the permeabilization itself is a result of the interaction of the plant defensins with components of the membrane, or with an intracellular target or signaling pathway triggered by the peptide [22].

The antifungal potency of a peptide in the presence of cations is of particular importance for evaluation of defense capacity against microorganisms in plants. Most plant defensins show little or no antifungal activity in the presence of monovalent and divalent cations in the growth medium at concentrations above 50 or $5 \mathrm{mM}$, respectively $[20,64,65]$. In these conditions, the interaction of plant defensins with their binding site dictates the specificity of the antifungal activity observed $[21,22,66]$. In the present study, PgD5 was shown to be highly heat stable and the antifungal activity against $V$. dahliae was unaffected in the presence of monovalent cation $\mathrm{K}^{+}$and moderately affected in the presence of divalent cation $\mathrm{Ca}^{++}$(Figure 7). This makes PgD5 an attractive candidate in the fields of agricultural biotechnology and therapeutic drug design, with possible application as a transferable resistance trait for molecular breeding of crop plants.

\section{Conclusions}

Screening of a EST database of $P$. glauca resulted in the identification of four homologues of $P g D 1$, designated $P g D 2-5$, and endopiceasin which is probably of fungal origin. $P g D 5$ codes for a defensin that is fully conserved within the genus Picea. Recombinant PgD5 displayed nonmorphogenic antifungal activity, possibly associated with membrane permeabilization, at low concentrations against several fungal plant pathogens. The strong antifungal activity of PgD5 against $V$. dahliae even in high-ionic-strength medium is of special interest, making PgD5 an attractive candidate for engineering pathogen-resistant crops.

\section{Methods}

Plant material, microbial strains

Leaves from Picea glauca were collected from the botanical garden of the University of Oulu, Oulu (Finland). 
Escherichia coli DH5 $\alpha$ (maintained in our laboratory) was used for cloning and plasmid amplification. E. coli BL21 (origami pLys S) DE3 (Novagen, USA) was used as the expression host. Candida utilis and Saccharomyces cerevisiae were obtained from our collection in the Pharmazeutische Mikrobiologie des Universitatsklinikums, Bonn, Germany. Yeasts were maintained on potato dextrose agar (PDA). Rizoctonia solani (CBS 340.58), Fusarium oxysporum (CBS 619.87), Botrytis cinerea (CBS 125.58) and Verticillium dahliae (CBS 110272) were purchased from the CBS-KNAW Fungal Biodiversity Center in Utrecht, Netherlands. Fungi were also maintained in PDA at $25^{\circ} \mathrm{C}$ until sporulation. Spores were harvested in $\mathrm{dH}_{2} \mathrm{O}$ and spore concentration was determined using a Thoma chamber.

\section{Database searches and primer design}

Plant defensin-encoding sequences were discovered by screening the $P$. glauca EST database of the National Centre for Biotechnological Information (NCBI) using TBLASTN. This database was screened using the amino acid sequences of Picea glauca defensin 1 [GenBank:AAR84643], Ginkgo biloba defensin 1 [GenBank:AY695796.1], Pinus sylvestris defensin 1 [GenBank:EF455616.1], Pinus sylvestris defensin 2 [GenBank:EF455617.1], Pinus sylvestris defensin 3 [GenBank:JN980401.1] and Pseudoplectania nigrella defensin [plectasin, Swiss-Prot:Q53I06.1]. Primers were designed based on the EST clones GQ01307_A13 and GQ0132. B7_K03 to identify the complete coding sequences encoded within the ESTs.

\section{Primer design and defensin genes amplification}

Genomic DNA was isolated from P. glauca leaves. Leaf tissue was collected, frozen in liquid nitrogen and ground to a fine powder using mortar and pestle. The DNA was extracted by the CTAB method [67].

The genomic DNA isolated from P. glauca was used as the template in PCR to isolate the complete coding sequences of $\operatorname{PgD} 5$ and endopiceasin. The two primer sets used were forward primer PgD5F (5'-ATGGAGAAGAGAATGGGCAG-3') and reverse primer PgD5rev (5'TTAACAGGGTTTCTCGCAGA-3') for PgD5, and EST_K03F (5'- ATGAAG TTCACCATCTCCATC-3') together with reverse primer EST_K03rev (5'-CTAGTAGCACTTGCAAGTGGT-3') for endopiceasin. Amplification conditions were $95^{\circ} \mathrm{C}$ for 3 minutes, 30 cycles: $95^{\circ} \mathrm{C}$ for $1 \mathrm{~min}, 58^{\circ} \mathrm{C}$ for $45 \mathrm{~s}, 72^{\circ} \mathrm{C}$ for $45 \mathrm{~s}$ and final extension at $72^{\circ} \mathrm{C}$ for 7 minutes. The gel-eluted (QIAquick PCR Purification Kit, Qiagen) amplification products were ligated into the GEM $^{\circledR}$-T vector (PROMEGA Corporation, Madison, USA) and submitted for sequencing to Eurofins MWG Operon. Nucleotide and deduced amino acid sequence comparisons were made using the BLAST algorithm.

\section{Sequence analysis of $P g D 5$ within the genus Picea}

Leaves from several Picea species (P. abies, P. smithiana, $P$. mariana, $P$. orientalis, $P$. omorika and $P$. wilsonii) were collected from the botanical garden of the University of Bonn, Bonn (Germany) and genomic DNA was isolated as described above. Gene homologues of PgD5 were isolated from the different Picea species as described above. Genomic sequences obtained for the different Picea species were analyzed and aligned using ClustalX [68].

\section{Bioinformatical analysis of the deduced amino acids sequence of $P g D 5$}

The deduced amino acid sequence of PgD5 was produced in VectorNTi and analyzed using the BLASTP algorithm. Homologous sequences identified were further aligned using ClustalX [68]. The deduced PgD5 sequence was also subjected to disulfide bridge analyses using DiANNA [69]; secondary structure analysis as well as homology modeling was done using the I-TASSER server $[70,71]$. The peptide structure of PgD5 was evaluated for the presence of a signal peptide sequence with SignalP [72] and sub-cellular localization directed by signal peptide was predicted on the Proteome Analyst Specialized Sub-cellular Localization Server (PA-SUB) [73]. The peptide mass prediction was done with the Expasy tool, PEPTIDE-MASS [74].

\section{Recombinant production of PgD5 in E. coli}

The Champion ${ }^{\mathrm{T \mu}}$ pET SUMO Expression System was purchased from Invitrogen and used for the recombinant production of PgD5 in E. coli BL21 (Origami pLys S) DE3. This system allows for the production of a His6tag at the N-terminus of the SUMO protein followed by mature PgD5 at the C-terminus ( $\mathrm{His}_{6}-\mathrm{SUMO}-\mathrm{PgD} 5$ ). pGEM-T-PgD5 served as the template to prepare the mature PgD5 sequence by PCR. The expected 153-bp fragment encoding the mature form of PgD5 was amplified with the primer set mPgD5FWD (5'-CGGATGTGTGAGTCGCAGA-3') and mPGD5rev (5'-TTAACAGGG TTTCTCGCAGA-3'). The gel-eluted amplification product was ligated into the linearized pET-SUMO T/A vector and termed pET-SUMO/PgD5. pET-SUMO/PgD5 was transformed into E. coli $\mathrm{DH} 5 \alpha$ and the identity and the correct orientation of the sequence was confirmed by sequencing.

The pET-SUMO/PgD5 plasmid that had been constructed was transformed into E. coli (Origami pLys S) DE3 expression strain and bacterial colonies were selected by plating onto Luria-Bertani (LB) agar with 25 $\mu \mathrm{g} / \mathrm{mL}$ kanamycin, $34 \mu \mathrm{g} / \mathrm{mL}$ chloramphenicol and 12.5 $\mu \mathrm{g} / \mathrm{mL}$ tetracycline. A single colony was inoculated to 10-mL LB medium containing antibiotics and grown overnight at $37^{\circ} \mathrm{C}$. The overnight cultures were diluted 
1:50 (v/v) in $1 \mathrm{~L}$ of the same medium without antibiotics and grown in the shaking incubator at $37^{\circ} \mathrm{C}$ and 200 rpm until an optical density $\left(\mathrm{OD}_{600}\right)$ of 0.6. Protein expression was induced by adding $0.4 \mathrm{mM}$ IPTG and subsequent culturing at $25^{\circ} \mathrm{C}$ overnight with shaking. Cells were harvested by centrifugation at $10,000 \mathrm{xg}$ for $15 \mathrm{~min}$ at $4^{\circ} \mathrm{C}$ and the pellets were stored at $-80^{\circ} \mathrm{C}$ until protein extraction.

\section{Purification of recombinant fusion protein}

Each gram of pelleted cells (wet weight) expressing $\mathrm{His}_{6}{ }^{-}$ SUMO-PgD5 was resuspended in $10 \mathrm{~mL}$ BugBuster Protein Extraction Reagent (Novagen) according to the manual, complemented with $1 \mathrm{mM}$ PSMF. The suspensions were gently mixed to facilitate cell lysis and centrifuged at $10,000 \mathrm{xg}$ for $20 \mathrm{~min}$ at $4^{\circ} \mathrm{C}$. The supernatant was applied to the pre-equilibrated Ni-NTA column with binding buffer (50 mM NaH $\mathrm{PO}_{4}, 500 \mathrm{mM} \mathrm{NaCl}$, $20 \mathrm{mM}$ imidazole, $\mathrm{pH}$ 7). After extensive washing with binding buffer, the fusion protein was eluted with eluting buffer (50 mM NaH2PO4, $500 \mathrm{mM} \mathrm{NaCl}, 250 \mathrm{mM}$ imidazole, $\mathrm{pH} 8$ ). The eluted fractions containing the fusion protein were pooled and dialyzed overnight at $4^{\circ} \mathrm{C}$ against $10 \mathrm{mM}$ Tris- $\mathrm{HCl}$ containing $150 \mathrm{mM} \mathrm{NaCl}, \mathrm{pH}$ 8 , and concentrated to a final $1-5 \mathrm{~mL}$ volume. The recombinant PgD5 was digested with 1U SUMO protease per $50 \mu \mathrm{g}$ fusion protein in the presence of $0.5 \mathrm{mM}$ DTT for $1 \mathrm{~h}$ at $30^{\circ} \mathrm{C}$.

Reverse phase-HPLC was used for the final PgD5 purification step using a reverse-phase C18 column $(0.46 \mathrm{~cm}$ $\times 25 \mathrm{~cm}$ ). The chromatography was performed at a flow rate of $1 \mathrm{~mL} / \mathrm{min}$ and elution was carried out with a linear gradient from $100 \%$ solvent A (TFA $0.1 \%$ ) to $60 \%$ of solvent B (100\% acetonitrile containing $0.1 \%$ TFA) over $40 \mathrm{~min}$. The eluate was monitored by on-line measurement of the absorbance at $220 \mathrm{~nm}$. Eluted peptide was freeze-dried, dissolved in distilled water at a final concentration of $100 \mu \mathrm{g} / \mathrm{mL}$ and stored at $-20^{\circ} \mathrm{C}$.

\section{Analysis and identification of recombinant PgD5}

The purity of eluted PgD5 was evaluated by separating 1 $\mu \mathrm{g}$ peptide on a $15 \%$ [w/v] Tris-Tricine gel [75]; after separation the peptide band was visualized by staining with SimplyBlue $^{\mathrm{TM}}$ SafeStain (Invitrogen). The molecular mass of purified peptide was analyzed on a MALDI-TOF-MS system (BIFLEX III, Bruker Daltonics GmbH). Aliquots of $1 \mu \mathrm{L}$ were mixed with $2 \mu \mathrm{L}$ of $\alpha$-cyano-4-hydroxycinnamic acid and spotted onto a ground-steel MALDI target plate (Bruker Daltonics $\mathrm{GmbH}$ ) and air dried at room temperature. Spectra were recorded in the linear mode at a laser frequency of $20 \mathrm{~Hz}$ within a mass range of 1000$6000 \mathrm{Da}$ and further analyzed using FlexAnalysis (version 2.0) software (Bruker Daltonics, $\mathrm{GmbH}$ ). The spectra were externally calibrated using peptide standards. The mass obtained for the peptide was compared to the predicted mono-isotopic mass of the peptide generated with the Expasy-Compute $\mathrm{pI} / \mathrm{Mw}$ tool.

\section{Antimicrobial activity assays}

The activity of PgD5 against the yeasts $S$. cerevisiae and C. albicans was determined using the microbroth dilution method in a 96-well microtiter plate (Nunc U96 microtiter plates) [76]. Briefly, wells were filled with 50 $\mu \mathrm{l}$ of serial dilutions of the peptide and mixed with 50 $\mathrm{mL}$ of Potato Dextrose Broth (PDB) containing $2 \times 10^{6}$ colony forming units $(\mathrm{CFU} / \mathrm{mL})$. The $20 \mathrm{mM}$ Tris solution ( $\mathrm{pH} 8.0)$ was added as the negative control. Experiments were performed at least in three replicates. Microbial growth was assessed by measuring the optical density at $600 \mathrm{~nm}$ after $16 \mathrm{~h}$ incubation at $30^{\circ} \mathrm{C}$ without shaking. The minimal inhibitory concentration (MIC) was defined as the lowest concentration of peptide that induced no change in optical density.

Quantitative antifungal activity of PgD5 was assessed using a microspectrophotometric assay in a 96-well microtiter plate (Nunc F96 microtiter plates) [77] with the following fungal pathogens: F. oxysporum, B. cinerea and $V$. dahliae. Each well contained 1000 fungal spores in $100 \mu \mathrm{l}$ half-strength Potato Dextrose Broth (PDB) and purified PgD5 at concentrations ranging from 1 to 50 $\mu \mathrm{g} / \mathrm{mL}$. Control reactions contained no peptide. Plates were incubated in the dark at $23^{\circ} \mathrm{C}$ for 3 days, with microspectrophotometric readings taken every 24 hours at $\mathrm{A}_{595}$. PgD5 defensin activity was scored after $48 \mathrm{~h}$ in the case of the fungi $F$. oxysporum and $B$. cinerea and after $72 \mathrm{~h}$ in the case of $V$. dahliae, and was expressed as a percentage of growth inhibition. Growth inhibition percentage is defined as $100 \times$ the ratio of the $A_{595}$ of the control minus the $A_{595}$ of the sample over the $A_{595}$ of the control [76]. $\mathrm{IC}_{50}$ is defined as the protein concentration at which $50 \%$ inhibitions was reached.

Antifungal activity was also tested in vitro against the fungus $R$. solani. Fungal discs of uniform size were inoculated at the center of the Petri dish containing about 15 $\mathrm{mL} \mathrm{PDB}$ and incubated at $25^{\circ} \mathrm{C}$. When the mycelia reached $6 \mathrm{~cm}$ in diameter, sterile Whatman no.1 filter paper discs (1 cm diameter) were placed on the plate at equal distances from the center. Various quantities of purified PgD5 were added to each disk. The plates were incubated at $25^{\circ} \mathrm{C}$ and observed periodically until the mycelial growth had enveloped control discs containing sterile distilled water growth inhibition zones had formed around the discs containing active preparations of PgD5.

\section{Sytox green uptake}

The ability of PgD5 to cause plasma membrane permeabilization was measured by SYTOX GREEN (Molecular Probes; Invitrogen Corp, Carlsbad, CA, USA) 
uptake as described previously [78] on $F$. oxysporum, $B$. cinerea and $V$. dahliae. The permeabilization assay consisted of $200 \mathrm{~mL}$ half-strength PDB containing fungal spores $\left(2 \times 10^{4}\right.$ spores $\left./ \mathrm{mL}\right)$ and PgD5 peptide at concentrations of $11 \mu \mathrm{g} / \mathrm{mL}$ for $F$. oxysporum, $4 \mu \mathrm{g} / \mathrm{mL}$ for $B$. cinerea and $2 \mu \mathrm{g} / \mathrm{mL}$ for the $V$. dahliae isolate. Fungal strains were incubated at $25^{\circ} \mathrm{C}$ in the presence of PgD5 for 48 hours. Control samples contained no PgD5. After incubation the samples were washed with $0.1 \mathrm{M}$ Tris$\mathrm{HCl}, \mathrm{pH} 8$ and stained with $0.2 \mu \mathrm{M}$ SYTOX Green in 96-well microplates for $30 \mathrm{~min}$ at $25^{\circ} \mathrm{C}$ with periodic agitation, followed by observation in a phase-contrast microscope (Axiophoto Zeiss) equipped with a fluorescence filter set for fluorescein detection (excitation wavelengths, 450 to $490 \mathrm{~nm}$; emission wavelength, 500 $\mathrm{nm})$. Intracellular fluorescence is indicative of a compromised fungal membrane. SYTOX Green uptake in S. cerevisiae was measured similarly, except the cell density was approximately $2 \times 10^{8}$ cells per $\mathrm{mL}$, and incubation was $1 \mathrm{~h}$ at $30^{\circ} \mathrm{C}$ in the presence of PgD5 at a concentration of $11 \mu \mathrm{g} / \mathrm{mL}$.

\section{Heat stability assessment and effect of ions on purified PgD5 activity}

The stability of the purified PgD5 peptide was assessed by an antifungal assay as described above. The heat stability of the peptide was assessed at the final peptide concentration of $2 \mu \mathrm{g} / \mathrm{mL}$ against $V$. dahliae spores, with the peptide being pretreated at $25^{\circ} \mathrm{C}, 50^{\circ} \mathrm{C}, 75^{\circ} \mathrm{C}$ and $100^{\circ} \mathrm{C}$ for 30 $\mathrm{min}$, before starting with the antifungal assay. The activity of PgD5 was scored against the control reaction conducted at $25^{\circ} \mathrm{C}$. In a similar assay, the effect of the presence of cations on the antifungal activity of PgD5 was also tested. The cations were added to the medium at concentrations of $10 \mathrm{mM}$ and $50 \mathrm{mM}$ for $\mathrm{KCl}$, and $1 \mathrm{mM}$ and 5 $\mathrm{mM}$ for $\mathrm{CaCl}_{2}$. The effect of monovalent and divalent cations on PgD5 activity was scored against the control reaction conducted without cations.

\section{Additional files}

Additional file 1: Alignment analysis of the deduced amino acid sequence of endopiceasin discovered by database searches. EST GQ0132.B7_K03 (endopiceasin) was found by screening the P. glauca EST database using the amino acid sequence of plectasin. The percentage similarity compared to plectasin is indicated in the last column.

Additional file 2: The complete coding sequence and the deduced amino acid sequence of endopiceasin encoded within the EST GQ0132.B7 K03. The underlined amino acids represent the signal peptide, the amino acids in red indicate the pro-peptide while blue amino acids indicate the mature peptide.

Additional file 3: Alignment of the mature region of endopiceasin with other members of the defensins family. Alignment analysis of endopiceasin. The percentage similarity compared to endopiceasin is indicated in the last column. [Swiss-Prot:Q53106.1] plectasin from fungi Pseudoplectania nigrella; [GenBank:BAB41027.1] defenisn A from arthropod
Ornithodoros moubata; [GenBank:AB152817.1] defensin B from arthropod Argas monolakensis. The six-cysteine residues are indicated by yellow and the disulphide bridge pattern is shown below.

Additional file 4: Alignment analysis of $P g D 5$ genomic copies isolated from different Picea sp. The differences between the sequences are indicated by yellow. The intron sequences are indicated in lowercase.

\section{Authors' contributions}

HGS and HHK supervised the work and helped with conceptual design and manuscript preparation as well as final data analysis. PP, AMP and DR performed conceptual and experimental design and PP was responsible for all the research procedures, data analysis and writing the paper. The authors declare no conflicts of interest. All authors read and approved the final manuscript.

\section{Acknowledgements}

We would like to thank the following members of the Institut für Mikrobiologie und Biotechnologie der Universität Bonn, M Josten for the LC-MS analysis, Dr P Saas for the live cell imaging microscopy and I Stock for revising the manuscript. The work was financially supported by the Marie Curie Industry-Academia Partnership and Pathways (IAPP) funded by the EU $7^{\text {th }}$ Framework Programme for Research and Technological Development, New Antimicrobials (NAM) Project Project (PIAP-GA-2008-218191).

\section{Author details}

${ }^{1}$ Institut für Mikrobiologie und Biotechnologie, der Universität Bonn, Meckenheimer, Allee, Bonn 167, 53115, Germany. ${ }^{2}$ Department of Biology, University of Oulu, Linnanmaa, OuluPO Box 3000 A6FIN-90014, Finland. ${ }^{3}$ Novozymes A/S, Krogshoejvej, Bagsvaerd 36, DK-2880, Denmark.

Received: 22 June 2012 Accepted: 28 September 2012 Published: 5 October 2012

\section{References}

1. Dixon R, Harrison M, Lamb C: Early events in the activation of plant defense responses. Annual Review Phytopath 1994, 32:479-501.

2. Lay FT, Anderson MA: Defensins-components of the innate immune system in plants. Curr Prot Pept Sci 2005, 6(1):85-101.

3. van Loon LC, Rep M, Pieterse CMJ: Significance of inducible defense-related proteins in infected plants. Annu Rev Phytopathol 2006, 44:135-162.

4. da Cunha L, McFall AJ, Mackey D: Innate immunity in plants: a continuum of layered defenses. Microbes Infect 2006, 8(5):1372-1381.

5. Jones DA, Takemoto D: Plant innate immunity - direct and indirect recognition of general and specific pathogen-associated molecules. Curr Opin Immunol 2004, 16(1):48-62.

6. Broekaert WF, Terras FR, Cammue BP, Osborn RW: Plant defensins: novel antimicrobial peptides as components of the host defense system. Plant Physiol 1995, 108(4):1353-1358.

7. Benko-Iseppon AM, Galdino SL, Calsa TJ, Kido EA, Tossi A, Belarmino LC, Crovella S: Overview on plant antimicrobial peptides. Curr Prot Pept SCi 2010, 11:181-188.

8. Thomma BP, Cammue BP, Thevissen K: Plant defensins. Planta 2002, 216(2):193-202.

9. Garcia-Olmedo F, Molina A, Alamillo JM, Rodriguez-Palenzuela P: Plant defense peptides. Biopolymers 1998, 47(6):479-491.

10. Almeida MS, Cabral KM, Kurtenbach E, Almeida FC, Valente AP: Solution structure of pisum sativum defensin 1 by high resolution NMR: plant defensins, identical backbone with different mechanisms of action. $J \mathrm{Mol}$ Biol 2002, 315:749-757.

11. Fant F, Vranken W, Broekaert WF, Borremans F: Determination of the three dimensional solution structure of raphanus sativus antifungal protein 1 by 1 H NMR. J Mol Biol 1998, 279:257-270.

12. Shiau YS, Horng SB, Chen CS, Huang PT, Lin C, Hsueh YC, Lou KL: Structural analysis of the unique insecticidal activity of novel mungbean defensin VrD1 reveals possibility of homoplasy evolution between plant defensins and scorpion neurotoxins. J Mol Recognit 2006, 19:441-450.

13. Kristensen AK, Brunstedt J, Nielsen JE, Mikkelsen JD, Roepstorff P, Nielsen KK. Processing, disulfide pattern, and biological activity of a sugar beet 
defensin, AX2, expressed in Pichia pastoris. Protein Expr Purif 1999, 16(3):377-387.

14. Lay FT, Schirra HJ, Scanlon MJ, Anderson MA, Craik DJ: The threedimensional solution structure of $\mathrm{NaD} 1$, a new floral defensin from nicotiana alata and its application to a homology model of the crop defense protein alfAFP. J Mol Biol 2003, 325(1):175-188.

15. Yount NY, Yeaman MR: Multidimensional signatures in antimicrobial peptides. Proc Natl Acad Sci 2004, 101(19):7363-7368.

16. Yount NY, Andrés MT, Fierro JF, Yeaman MR: The gamma-core motif correlates with antimicrobial activity in cysteine-containing kaliocin-1 originating from transferrins. Biochim Biophys Acta 2007, 1768(11):2862-2872.

17. Terras FR, Eggermont K, Kovaleva V, Raikhel NV, Osborn RW, Kester A, Rees SB, Torrekens S, Van Leuven F, Vanderleyden J, Cammue B, Broekaert W: Small cysteine-rich antifungal proteins from radish: their role in host defense. Plant Cell 1995, 7(5):573-588.

18. Carvalho A, Gomes VM: Plant defensins -prospects for the biological functions and biotechnological properties. Peptides 2009, 30:1007-1020.

19. Wong JH, Xia L, Ng TB: A review of defensins of diverse origins. Curr Prot Pept Sci 2005, 6:85-101.

20. Osborn RW, De Samblanx GW, Thevissen K, Goderis I, Torrekens S, Van Leuven F, Attenborough S, Rees SB, Broekaert WF: Isolation and characterisation of plant defensins from seeds of asteraceae, fabaceae, Hippocastanaceae and Saxifragaceae. FEBS Lett 1995, 368:257-262.

21. Thevissen K, Ferket KK, Francois IE, Cammue BP: Interactions of antifungal plant defensins with fungal membrane components. Peptides 2003, 24:1705-1712.

22. Thevissen $\mathrm{K}$, Warnecke DC, Francois IE, Leipelt M, Heinz E, Ott C, Zahringer $U$, Thomma BP, Ferket KK, Cammue BP: Defensins from insects and plants interact with fungal glucosylceramides. J Biol Chem 2004, 279:3900-3905.

23. Thevissen K, Cammue BP, Lemaire K, Winderickx J, Dickson RC, Lester RL, Ferket KK, Van Even F, Parret AH, Broekaert WF: A gene encoding a sphingolipid biosynthesis enzyme determines the sensitivity of Saccharomyces cerevisiae to an antifungal plant defensin from dahlia (Dahlia merckii). Proc Natl Acad Sci 2000, 97(17):9531-9536.

24. Thevissen K, Franc, ois IEJA, Takemoto JY, Ferket KKA, Meert EMK, Cammue BPA: DmAMP1, an antifungal plant defensin from dahlia (Dahlia merckii), interacts with sphingolipids from Saccharomyces cerevisiae. FEMS Microbiol Lett 2003, 226:169-173.

25. van der Weerden NL, Lay FT, Anderson MA: The plant defensin, NaD1, enters the cytoplasm of Fusarium oxysporum hyphae. J Biol Chem 2008, 283:14445-14452.

26. Lobo DS, Pereira IB, Fragel-Madeira L, Medeiros LN, Cabral LM, Faria J, Bellio M, Campos RC, Linden R, Kurtenbach E: Antifungal Pisum sativum defensin 1 interacts with Neurospora crassa cyclin F related to the cell cycle. Biochemistry 2007, 46:987-996.

27. Bloch $C J$, Richardson M: A new family of small $(5 \mathrm{kDa})$ protein inhibitors of insect a-amylases from seeds of sorghum (Sorghum bicolor (L) Moench) have sequence homologies with wheat $\gamma$-purothionins. FEBS Lett 1991, 279(1):101-104

28. Chen KC, Lin CY, Kuan CC, Sung HY, Chen CS: A novel defensin encoded by a mungbean CDNA exhibits insecticidal activity against bruchid. $J$ Agric Food Chem 2002, 50:7258-7263.

29. Liu YJ, Cheng CS, Lai SM, Hsu MP, Chen CS, Lyu PC: Solution structure of the plant defensin $\mathrm{VrD} 1$ from mung bean and its possible role in insecticidal activity against bruchids. Proteins 2006, 63:777-786.

30. Mendez E, Moreno A, Colilla F, Pelaez F, Limas GG, Mendez R, Soriano F, Salinas $M$, de Haro C: Primary structure and inhibition of protein synthesis in eukaryotic cell-free system of a novel thionin, gamma-hordothionin, from barley endosperm. Eur J Biochem 1990, 194:533-539.

31. Mendez E, Rocher A, Calero M, Girbes T, Citores L, Soriano F: Primary structure of omega-hordothionin, a member of a novel family of thionis from barley endosperm, and its inhibition of protein synthesis in eukaryotic and prokaryotic cell-free systems. Eur J Biochem 1996, 239:67-73.

32. Melo FR, Rigden DJ, Franco OL, Mello LV, Ary MB: Grossi de Sa MF, Bloch C Jr: Inhibition of trypsin by cowpea thionin: characterization, molecular modeling, and docking. Proteins 2002, 48(2):311-319.

33. Mirouze $M$, Sels J, Richard $O$, Czernic P, Loubet $S$, Jacquier $A$, François $\mathrm{IE}_{\text {, Cammue } B P}$, Lebrun $M$, Berthomieu $P$, Marquès $L$ : A putative novel role for plant defensins: a defensin from the zinc hyperaccumulating plant, Arabidopsis halleri, confers zinc tolerance. Plant J 2006, 47:329-342.
34. Spelbrink RG, Dilmac N, Allen A, Smith TJ, Shah DM, Hockerman GH: Differential antifungal and calcium channel-blocking activity among structurally related plant defensins. Plant Physiol 2004, 135:2055-2067.

35. Kushmerick C, Castro MS, Cruz JS, Bloch C Jr, Beirão PS: Functional and structural features of g-zeathionins, a new class of sodium channel blockers. FEBS Lett 1998, 440:302-306.

36. Huang GJ, Lai HC, Chang YS, Sheu MJ, Lu TL, Huang SS, Lin YH: Antimicrobial, dehydroascorbate reductase, and monodehydroascorbate reductase activities of defensin from sweet potato [Ipomoea batatas (L.) Lam. 'tainong 57'] storage roots. J Agric Food Chem 2008, 56:2989-2995.

37. Chen Z, Gallie DR: Dehydroascorbate reductase affects leaf growth, development and function. Plant Physiol 2006, 142:775-787.

38. Wong $\mathrm{JH}$, Zhang $\mathrm{XQ}$, Wang $\mathrm{HX}, \mathrm{Ng} \mathrm{TB}$ : Amitogenic defensin from white cloud beans (Phaseolus vulgaris). Peptides 2006, 27:2075-2081.

39. Ye XY, Ng TB: Peptides from pinto bean and red bean with sequence homology to cowpea 10-kda protein precursor exhibit antifungal, mitogenic, and HIV-1 reverse transcriptase-inhibitory activities. Biochem Biophys Res Commun 2001, 285:424-429.

40. Ye XY, Ng TB: A new antifungal peptide from rice beans. J Peptide Res 2002, 60:81-87.

41. Pavy N, Paule C, Parsons L, Crow JA, Morency MJ, Cooke JEK, Johnson JE, Noumen E, Guillet-Claude C, Butterfield Y, Barber S, Yang G, Liu J, Stott J, Kirkpatrick R, Siddiqui A, Holt R, Marra M, Séguin A, Retzel E, Bousquet J, Mackay J: Generation, annotation, analysis and database integration of 16,500 white spruce EST clusters. BMC Genomics 2005, 6:144.

42. Rigault P, Boyle B, Lepage P, Cooke JE, Bousquet J, MacKay JJ: A white spruce gene catalog for conifer genome analyses. Plant Physiol 2011 157(1):14-28.

43. Pervieux I, Bourassa M, Laurans F, Hamelin RC, Séguin A: A spruce defensin showing strong antifungal activity and increased transcript accumulation after wounding and jasmonate treatments. Physiological and Molecular Plant Pathology 2004, 64:331-341.

44. Sawano Y, Miyakawa T, Yamazaki H, Tanokura M, Hatano K: Purification, characterization, and molecular gene cloning of an antifungal protein from Ginkgo biloba seeds. Biol Chem 2007, 388(3):273-280.

45. Zhu S: Discovery of six families of fungal defensin-like peptides provides insights into origin and evolution of the CSalphabeta defensins. Mol Immunol 2008, 45:828-838.

46. Kovalyova VA, Hut RT: Molecular cloning and characterization of Scotch pine defensin 2. Cytol and Genet 2008, 42(6):408-412.

47. de Beer A, Vivier MA: Vv-AMP1, a ripening induced peptide from Vitis vinifera shows strong antifungal activity. BMC Plant Biol 2008, 8:75.

48. Fernández-Ocaña A, García-López MC, Jiménez-Ruiz J, Saniger L, Macías D, Navarro F, Oya R, Belaj A, de la Rosa R, Corpas FJ, Barroso JB, Luque F: Identification of a gene involved in the juvenile-to-adult transition (JAT) in cultivated olive trees. Tree Genetics \& Genomes 2010, 6:891-903.

49. Mygind PH, Fischer RL, Schnorr KM, Hansen MT, Sönksen CP, Ludvigsen S, Raventós D, Buskov S, Christensen B, De Maria L, Taboureau O, Yaver D, Elvig-Jørgensen SG, Sørensen MV, Christensen BE, Kjaerulff S, Frimodt-Moller $\mathrm{N}$, Lehrer Rl, Zasloff M, Kristensen $\mathrm{HH}$ : Plectasin is a peptide antibiotic with therapeutic potential from a saprophytic fungus. Nature 2005 437(7061):975-980.

50. Wilmes M, Cammue BP, Sahl HG, Thevissen K: Antibiotic activities of host defense peptides: more to it than lipid bilayer perturbation. Nat Prod Rep 2011, 28(8):1350-1358.

51. Schneider T, Kruse T, Wimmer R, Wiedemann I, Sass V, Pag U, Jansen A, Nielsen AK, Mygind PH, Raventós DS, Neve S, Ravn B, Bonvin AM, De Maria L, Andersen AS, Gammelgaard LK, Sahl HG, Kristensen HH: Plectasin, a fungal defensin, targets the bacterial cell wall precursor Lipid II. Science 2010, 328(5982):1168-1172.

52. Sagaram US, Pandurangi R, Kaur J, Smith TJ, Shah DM: Structure-activity determinants in antifungal plant defensins MsDef1 and MtDef4 with different modes of action against Fusarium graminearum. PLoS One 2011 13:6(4).

53. Silverstein K, Graham M, Paape T, Van den Bosh K: Genome Organization of More 300 Defensin-like Genes In Arabidopsis. Plant Physiol 2005, 138(4):600-610.

54. Sharma $P$, Lönneborg A: Isolation and characterization of a cDNA encoding a plant defensin-like protein from roots of Norway spruce. Plant Mol Biol 1996, 31(3):707-712. 
55. Ganz T: Defensins: antimicrobial peptides of innate immunity. Nature Rev Immunol 2003, 3:710-720.

56. Lamberty M, Ades S, Uttenweiler-Joseph S, Brookhart G, Bushey D, Hoffmann JA, Bulet P: Insect immunity. Isolation from the lepidopteran Heliothis virescens of a novel insect defensin with potent antifungal activity. J Biol Chem 1999, 274:9320-9326.

57. Lacadena J: Martinez del Poxo A, Gasset M, Patino B, Campos-Olivas R, Vazquez C, Martinez-Ruiz A, Mancheno JM, Onaderra M, Gavilanes JG: Characterization of the antifungal protein secreted by the mould Aspergillus giganteus. Arc Biochem Biophys 1995, 324:273-281.

58. Saar DE, Polans NO, Sørensen PD, Duvall MR: Angiosperm DNA contamination by endophytic fungi: Detection and methods of avoidance. Plant Mol Biol Rep 2001, 19:249-260.

59. Camacho FJ, Gernandt DS, Liston A, Stone JK, Klein AS: Endophytic fungal DNA, the source of contamination in spruce needle DNA. Mol Ecol 1997, 6:983-987.

60. Arnold AE, Mejia LC, Kyllo D, Rojas El, Maynard Z, Robbins N, Herre EA: Fungal endophytes limit pathogen damage in a tropical tree. Proc Natl Acad Sci 2003, 100:15649-15654.

61. Broekaert WF, Cammue BPA, DeBolle MFC, Thevissen K, DeSamblanx G, Osborn RW: Antimicrobial peptides from plants. Crit Rev Plant Sci 1997, 16(3):297-323.

62. de Beer A, Vivier MA: Four plant defensins from an indigenous South African Brassicaceae species display divergent activities against two test pathogens despite high sequence similarity in the encoding genes. BMC Res Notes 2011, 4(1):459.

63. Slavokhotova AA, Odintsova TI, Rogozhin EA, Musolyamov AK, Andreev YA, Grishin EV, Egorov TA: Isolation, molecular cloning and antimicrobial activity of novel defensins from common chickweed (Stellaria media L.) seeds. Biochimie 2011, 93(3):450-456.

64. Terras FR, Schoofs HM, De Bolle MF, Van Leuven F, Rees SB, Vanderleyden J, Cammue BP, Broekaert WF: Analysis of two novel classes of plant antifungal proteins from radish (Raphanus sativus L.) seeds. J Biol Chem 1992, 267(22):15301-15309.

65. Terras FR, Torrekens S, Van Leuven F, Osborn RW, Vanderleyden J, Cammue BP, Broekaert WF: A new family of basic cysteine-rich plant antifungal proteins from Brassicaceae species. FEBS Lett 1993, 316(3):233-240.

66. Thevissen K, Francois IE, Aerts AM, Cammue BP: Fungal sphingolipids as targets for the development of selective antifungal therapeutics. Curr Drug Targets 2005, 6(8):923-928.

67. Pirttilä AM, Hirsikorpi M, Kämäräinen T, Jaakola L, Hohtola A: DNA Isolation Methods for Medicinal and Aromatic Plants. Plant Mol Biol Rep 2001, 19:273a.

68. Thompson JD, Gibson TJ, Plewniak F, Jeanmougin F, Higgins DG: The ClustalX windows interface: flexible strategies for multiple sequence alignment aided by quality analysis tools. Nucl Acids Res 1997, 25:4876-4882.

69. Ferrè F, Clote P: DiANNA: a web server for disulfide connectivity prediction. Nucl Acids Res 2005, 1:33.

70. Ambrish R, Kucukural A, Zhang Y: I-TASSER: a unified platform for automated protein structure and function prediction. Nat Protoc 2010, 5:725-738.

71. Zhang Y: I-TASSER server for protein 3D structure prediction. BMC Bioinformatics 2008, 9:40.

72. Bendtsen JD, Nielsen H, von Heijne G, Brunak S: Improved prediction of signal peptides: SignalP 3.0. J Mol Biol 2004, 340:783-795.

73. Proteome Analyst Specialized Subcellular Localization Server. http://www.cS ualberta.ca/\%7Ebioinfo/PA/Sub/index.html.

74. Expasy proteomics tools. http://us.expasy.org/tools/.

75. Schagger $\mathrm{H}$, von Jagow $\mathrm{G}$ : Tricine-sodium dodecyl sulfate-polyacrylamide gel electrophoresis for the separation of proteins in the range from 1 to 100 kDa. Anal Biochem 1987, 166:368-379.

76. Roberts WK, Selitrennikoff CP: Isolation and characterization of two antifungal proteins from barley. Biochim Biophys Acta 1986, 880:161-170.

77. Broekaert W, Terras F, Cammue B, Vandereyden J: An automated quantitive assay for fungal growth inhibition. FEMS Microbiol Lett 1990, 69:55-60.

78. Thevissen K, Terras FR, Broekaert WF: Permeabilization of fungal membranes by plant defensins inhibits fungal growth. Appl Environ Microbiol 1999, 65:5451-5458.

doi:10.1186/1471-2229-12-180

Cite this article as: Picart et al:: Identification of defensin-encoding genes of Picea glauca: characterization of PgD5, a conserved spruce defensin with strong antifungal activity. BMC Plant Biology 2012 12:180.

\section{Submit your next manuscript to BioMed Central and take full advantage of:}

- Convenient online submission

- Thorough peer review

- No space constraints or color figure charges

- Immediate publication on acceptance

- Inclusion in PubMed, CAS, Scopus and Google Scholar

- Research which is freely available for redistribution

Submit your manuscript at www.biomedcentral.com/submit 